\title{
PENERAPAN STANDAR AKUNTANSI DAN KUALITAS APARATUR TERHADAP LAPORAN KEUANGAN PEMERINTAH DAERAH (Studi Kasus pada Dinas Pekerjaan Umum dan Penataan Ruang Kabupaten Karimun)
}

\section{Tegor, Juliza, Yusmalina, Fauzan Haqiqi}

Program Studi Akuntansi, Fakultas Ilmu Sosial dan Humaniora, Universitas Karimun, Provinsi Kepulauan Riau, Indonesia

E-mail : tigor.belitong@gmil.com, fauzanhaqiqi.1986@gmail.com

\begin{abstract}
Abstrak
Penelitian ini dilakukan dengan menggunakan metode kuantitatif bertujuan untuk mengetahui penerapan standar akuntansi pemerintahan dan kualitas aparatur pemerintahan terhadap laporan keuangan pemerintah daerah pada Dinas Pekerjaan Umum Dan Penataan Ruang Kabupaten Karimun tahun 2019. sampel berjumlah 15 sampel penelitian. Adapun teknik analisis data yang digunakan dalam penelitian ini dengan menggunakan interview dan dengan membagikan kuesioner. Hasil penelitian ini menunjukkan bahwa standar akuntansi pemerintahan berpengaruh tidak signifikan terhadap laporan keuangan melalui mediasi kualitas aparatur pemerintahan. Koefisien jalur bertanda positif dapat diartikan bahwa hubungan standar akuntansi pemerintahan dengan laporan keuangan melalui kualitas aparatur pemerintahan adalah searah. Dengan demikian terdapat cukup bukti secara empiris untuk menolak hipotesis (H0) dan menerima hipotesis (H1).
\end{abstract}

Kata Kunci : : Penerimaan Kas, Pengeluaran Kas, dan Profit

\section{PENDAHULUAN}

Dalam penyusunan sebuah Laporan Keuangan Pemerintah Daerah (LKPD) yang berpedoman kepada Standar Akuntansi Pemerintah (SAP) untuk meningkatkan kualitas laporan keuangan sehingga laporan keuangan tersebut dapat mewujudkan transparansi dan akuntabilitas laporan keuangan, sehingga dapat tercapainya good governance. Laporan Keuangan Pemerintah Daerah (LKPD) setiap tahunnya mendapat penilaian berupa opini dari Badan Pengawasan Keuangan (BPK), Terdapat empat opini yang diberikan pemeriksa yaitu : Opini Wajar Tanpa Pengecualian (WTP), Opini Wajar Dengan Pengecualian (WDP), Opini Tidak Wajar (TP), dan Pernyataan Menolak Memberi Opini Atau Tidak Memberi Pendapat (TMP) terhadap Laporan Keuangan Pemerintah Daerah (LKPD). Dapat dikatakan bahwa Laporan Keuangan Suatu Pemerintah Daerah tersebut disajikan secara baik dan berkualitas.

Laporan Keuangan Pemerintah Daerah (LKPD) di Indonesia adalah sesuatu yang sangat lazim untuk di analisis dan di uji lebih lanjut. Dari berbagai macam daerah terdapat berbagai macam pula bentuk dan format laporan keuangan, Peraturan Pemerintah Nomor 71 Tahun 2010 tentang Standar Akuntansi Pemerintahan Daerah 
Kabupaten Karimun agar pengelolaan keuangan daerah dapat memenuhi dasar ekonomis, efesien, efektif, tertib, akuntabel, transparan dan komperhensif. Untuk mewujudkan laporan keuangan yang transparansi dan akuntabilitas pengelolaan keuangan harus dengan penyampaian pertanggungjawaban laporan keuangan yang memenuhi prinsip tepat waktu dan disusun dengan menerapkan standar akuntansi pemerintahan yang telah di tetapkan secara umum, sehingga dapat di perbandingkan dan tidak menyesatkan.

Penerapan sistem akuntansi dalam penyusunan laporan keuangan daerah merupakan hal yang mendasar dan sangat mempengaruhi kualitas laporan keuangan daerah. Dimana sistem akuntansi merupakan seni dalam proses pengumpulan data, pencatatan, pengikhtisaran atau pengelompokkan serta pelaporan keuangan untuk mempertanggungjawabkan Anggaran Pendapatan dan Belanja Daerah (APBD). Dalam laporan keuangan dan laporan asset kabupaten karimun masih belum sesuai dengan standar akuntansi pemerintah. Karena masih terdapat beberapa format dan alur dalam ssstem akuntansi yang belum termasuk kedalam system keuangan daerah pemerintah kabupaten karimun.

Dalam pelaksanaan Anggaran Pendapatan dan Belanja Daerah (APBD), Laporan Keuangan Pemerintah Daerah sebagai bentuk pertanggungjawaban harus disusun dan disajikan dalam sebuah sistem akuntansi pemerintah daerah yang handal, yang dapat dikerjakan dalam bentuk manual maupun menggunakan sistem aplikasi. Pada pemerintah Kabupaten Karimun belum sepenuhnya aparatur sipil negara dan laporan keuangan menggunakan Standar Akuntansi Pemerintahan Yang Sesuai Dengan Peraturan Pemerintah Nomor 71 tahun 2010. Dengan adanya Standar Akuntansi Pemerintahan (SAP) yang dapat menghasilkan informasi berupa Laporan keuangan pemerintah daerah yang relevan, andal, mudah dipahami dan dapat dibandingkan untuk pengambilan suatu keputusan baik ekonomi, sosial maupun politik.

\section{Standar Akuntansi Pemerintahan}

Berdasarkan Peraturan Pemerintah Nomor 71 tahun 2010 pasal 1 ayat (3) tentang Standar Akuntansi Pemerintahan (SAP) adalah prinsip-prinsip akuntansi yang diterapkan dalam menyusun dan menyajikan laporan keuangan pemerintahan dalam bentuk Pernyataan Standar Akuntansi Pemerintahan (PSAP). Laporan Keuangan Pokok 
menurut Standar Akuntansi Pemerintahan adalah Laporan Realisasi Anggaran, Neraca, Laporan Arus Kas, dan Catatan atas Laporan Keuangan.

Fakhrurazi (2010) menyatakan dengan adanya Standar Akuntansi Pemerintahan, laporan keuangan yang dihasilkan dapat memberikan informasi keuangan yang akurat, relevan dan dapat dibandingkan bagi stakeholders. dengan adanya standar akuntansi pemerintahan, pemerintahan dapat menyajikan dan menerapkan standar akuntansi pemerintahan sebagai pedoman dalam menyusun laporan keuangan daerah dalam mewujudkan suatu tata pemerintahan yang bergelar good governance.

\section{Kualitas Aparatur Pemerintah Daerah}

Aparatur Pemerintahan atau dikatakan Aparatur Sipil Negara (ASN) merupakan profesi bagi pegawai negeri sipil dan pegawai pemerintah dengan perjanjian kinerja yang bekerja pada instansi pemerintahan (UU RI Nomor 5 tahun 2014). Dalam suatu organisasi terutama tata pemerintahan Sumber Daya Manusia (SDM) sebagai penggerak jalannya organisasi. Organisasi membutuhkan sumber daya manusia yang berkualitas untuk dapat mencapai sebuah tujuan.

Pemerintah daerah sangat membutuhkan aparatur pemerintah yang professional dengan wawasan yang luas, memiliki kompetensi dibidangnya dan memiliki jiwa berkompetensi yang sportif. Aparatur pemerintah yang professional akan mampu menyelesaikan tugas dan pekerjaannya secara baik. Dengan kompetensi yang dimilikinya aparatur pemerintahan dapat melaksanakan tugas pokok dan fungsinya secara optimal. Aparatur pemerintahan yang berkualitas dalam bidang akuntansi (keuangan) menjadi tujuan utama untuk dapat tersusunnya laporan keuangan yang berkualitas. Artinya aparatur pemerintahan pada bidang akuntansi (keuangan) merupakan faktor yang berpengaruh terhadap laporan keuangan yang disusun pemerintah daerah.

\section{Laporan Keuangan}

Laporan keuangan adalah produk manajemen dalam mempertanggungjawabkan (Stewardship) penggunaan sumber daya dan sumber dana yang dipercayakan kepadanya (Gede E. Prasetya, 2005:5). Laporan keuangan merupakan laporan yang terstruktur mengenai posisi keuangan dan transaksi-transaksi yang dilakukan oleh suatu substansi 
pelaporan. Laporan keuangan pemerintah ditujukan untuk memenuhi tujuan umum pelaporan keuangan namun tidak untuk memenuhi kebutuhan khusus pemakainya.

\section{METODE PENELITIAN}

Penelitian ini menggunakan penelitian kausal komperatif dengan metode survey atau menggunakan kuesioner. Penelitian kausal komperatif merupakan penelitian dengan karakteristik masalah berupa sebab akibat antara dua variable atau lebih. Jenis data dalam penelitian ini adalah kuantitatif. Sumber data dalam penelitian ini adalah sumber data primer. Penelitian ini menggunakan teknik Structural Equation Modeling (SEM) berbasis variance atau yang lebih dikenal dengan SEM PLS (Partial Least Square) dan dibantu dengan software SMART PLS 2.0.M3.

\section{HASIL DAN PEMBAHASAN}

\section{Pengukuran Konstruk Penelitian (Outer model)}

Penelitian ini terdiri dari 3 (tiga) variabel laten yairtu: Penerapan Standar Akuntansi Pemerintahan (PSAP) (X1), Kualitas Aparatur Pemerintahan (SDM) (X2), dan Laporan Keuangan Pemerintah Daerah Kabupaten Karimun (Y). secara keseluruhan terdapat 16 (enam belas) indikator dan variabel laten dengan first order factor. Adapun hasil analisis diolah dengan menggunakan component based SEM dengan program SmartPls (Partial Least Square). Hasil model setelah diolah menggunakan component based SEM dengan software Smart PLS ini mengacu pada discriminant validity, convergent validity, dan composite reability.

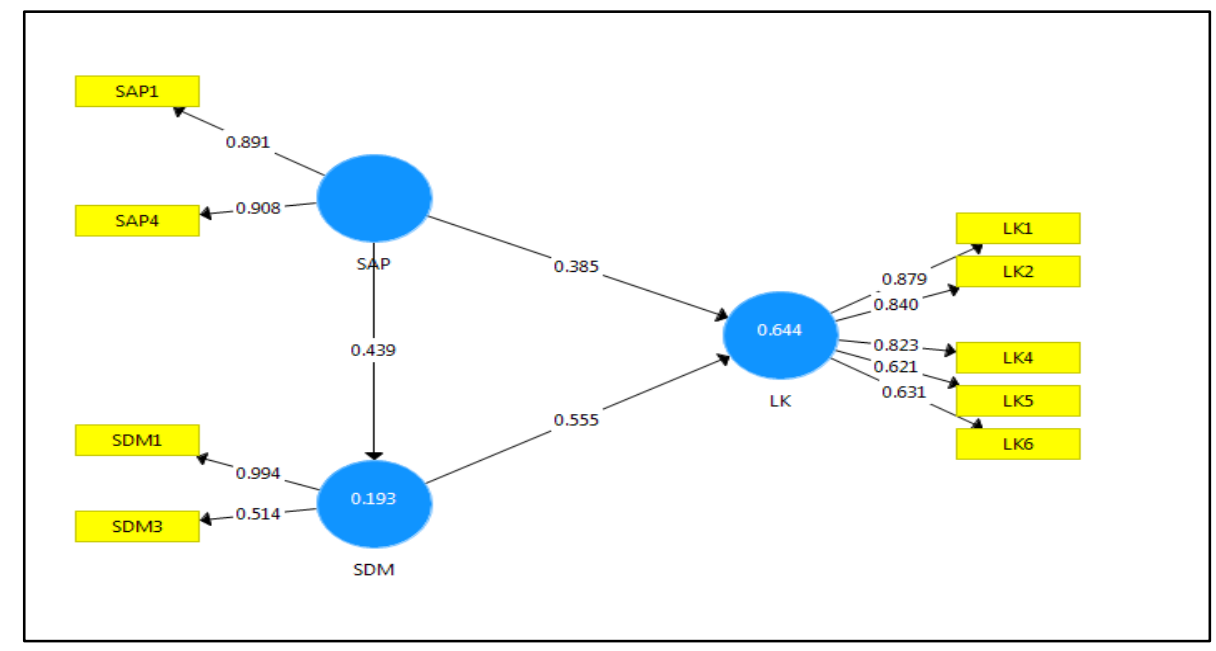

Gambar 1. Calculate Algorithm 


\section{Standar Akuntansi Pemerintahan}

Berdasarkan hasil analisis data, jika dilihat dari nilai estimasi pada outer loading untuk setiap indikator maka indikator mengakui dan mencatat persediaan berdasarkan hasil inventarisasi fisik pada akhir periode akuntansi paling penting dalam merefleksikan penerapan standar akuntansi pemerintahan. Hasil analisis menunjukkan loading factor tertinggi terdapat pada indikator SAP4 yaitu indikator mengakui dan mencatat persediaan berdasarkan hasil inventarisasi fisik pada akhir periode akuntansi sebesar 0,908, sehingga indikator tersebut mampu menjelaskan variaber penerapan standar akuntansi pemerintahan (X1) lebih baik dari pada indikator lainnya. Selanjutnya adalah indikator menyusun dan menyajikan laporan realisasi anggaran menggunakan akuntansi dan mencatat pendapatan berdasarkan asas bruto sebesar 0,891.

Dengan demikian dapat disimpulkan bahwa, mencatat persediaan berdasarkan hasil inventarisasi fisik pada akhir periode akuntansi yang dapat dicerminkan melalui penerapan standar akuntansi pemerintahan dalam bekerja memberikan kontribusi sebesar 90,8\% yang merupakan indikator yang paling terpenting dalam merefleksikan variabel standar akuntansi pemerintahan.

\section{Kualitas Aparatur Pemerintahan}

Pada gambar diatas menjelaskan tentang nilai loading factor variabel kualitas aparatur pemerintahan (X2) dimana nilai loading faktor indikator SDM1 yaitu memahami PP No. 71 Tahun 2010 tentang SAP, PP No.8 Tahun 2006 tentang Pelaporan Keuangan dan Kinerja Instansi Pemerintah, dan siklus akuntansi dengan baik sebesar 0,994 dan indikator SDM3 yaitu mengikuti pelatihan terkait dengan penatausahaan laporan keuangan sebesar 0,514. Dengan demikian variabel kualitas aparatur pemerintahan (X2) telah mampu dibentuk atau dijelaskan dengan baik oleh indikator memahami PP No. 71 Tahun 2010 tentang SAP, PP No.8 Tahun 2006 tentang Pelaporan Keuangan dan Kinerja Instansi Pemerintah, dan siklus akuntansi dengan baik dan indikator mengikuti pelatihan terkait dengan penatausahaan laporan keuangan dan kebutuhan berafiliasi atau dapat dikatakan valid secara convergent pada indikator tersebut.

Berdasarkan hasil analisis data, jika dilihat dari nilai estimasi pada outher loading untuk setiap indikator maka indikator SDM1 paling penting dalam merefleksikan 
variabel kualitas aparatur pemerintahan (X2). Hasil analisis menunjukkan loading faktor tertinggi terdapat pada indikator SDM1 yaitu indikator memahami PP No. 71 Tahun 2010 tentang SAP, PP No.8 Tahun 2006 tentang Pelaporan Keuangan dan Kinerja Instansi Pemerintah, dan siklus akuntansi dengan baik sebesar 0,994, sehingga indikator tersebut mampu menjelaskan variabel laporan keuangan (Y) lebih baik dari indikator lainnya. Selanjutnya loading faktor terkecil dari indikator menolak setiap intervensi dari atasan yang dapat menimbulkan pelanggaran terhadap peraturan sebesar 0,514.

\section{Laporan Keuangan}

Gambar diatas menjelaskan tentang nilai loading factor variabel laporan keuangan dimana nilai loading factor pada kelima indikator dari variabel laporan keuangan ratarata untuk masing-masing indikator berada diatas 0,700; akan tetapi indikator LK3 hanya sebesar 0,173 yakni berada lebih kecil dari batas kritis 0,700. Adapun indikator lainnya berada diatas dari batas kritis 0,700 yakni indikator LK1 yaitu Laporan keuangan yang di susun sesuai denga SAP, dengan informasi yang lengkap mencakup semua informasi akuntansi yang dapat digunakan dalam pengambilan keputusan. sebesar 0,879, indikator LK2 yaitu Laporan keuangan yang disusun selesai secara tepat waktu sehingga dapat digunakan untuk pengambilan keputusan saat ini dan mengoreksi keputusan masa lalu (feedback value) sebesar 0,840, indikator LK4 yaitu Informasi yang di sajikan dalam laporan keuangan menggambarkan dengan jujur transaksi dan peristiwa lainnya sehingga bebas dari pengertian yang menyesatkan dan kesalahan yang bersifat material sebesar 0,824, indikator LK5 yaitu Informasi yang termuat dalam laporan keuangan yang di susun selalu dapat dibandingkan dengan laporan keuangan periode sebelumnya sebesar 0,621 dan indikator LK6 yaitu Laporan yang di buat disusun secara sistematis sehingga mudah dimengerti dan dipahami sebesar 0,631.

\section{Average Variance Extracted (AVE)}

Nilai AVE yang lebih besar dari 0,500 menunjukkan bahwa discriminant validity telah tercapai, yaitu indikator yang digunakan telah mampu menjelaskan variabel yang dibentuk dari pada variabel lainnya, dan instrument variabel tersebut juga dikatakan valid discriminant. 
Tabel 1. Average Variance Extracted

\begin{tabular}{|c|c|c|}
\hline VARIABEL & AVE & KETERANGAN \\
\hline Standar Akuntansi Pemerintahan (SAP) & 0,809 & \multirow{3}{*}{$\begin{array}{c}\text { Indikator dikatakan valid secara } \\
\text { discriminant, jika nilai AVE-nya >0,5 }\end{array}$} \\
\hline Kualitas Aparatur Pemerintahan (SDM) & 0,626 & \\
\hline Laporan Keuangan (LK) & 0,588 & \\
\hline
\end{tabular}

Berdasarkan hasil tabel diatas dapat dilihat bahwa nilai composite reliability pada variabel standar akuntansi pemerintahan (X1), kualitas aparatur pemerintahan (X2) dan laporan keuangan (Y) berada diatas lebih besar dari 0,5 maka dapat dikatakan bahwa indikator instrument penelitian ini valid secara discriminant. Hal tersebut dapat diartikan bahwa variabel-variabel laten yang digunakan reliabilitas komposit yang baik. Selain itu nilai Cronbach alpha pada standar akuntansi pemerintahan (X1) sebesar 0,809, kualitas aparatur pemerintahan (X2) sebesar 0,626 dan laporan keuangan (Y) sebesar 0,588 lebih besar dari 0,50 dan dapat dikatakan variabel tersebut memiliki reabilitas yang tinggi. Dengan demikian, bahwa seluruh instrument yang digunakan dalam penelitian ini telah memenuhi kreteria atau layak untuk digunakan

\section{Pengujian Goodnees Of Fit (Inner Model)}

Tabel 2.

Nilai Goodneess Of Fit (R-square)

\begin{tabular}{|l|c|c|}
\hline \multicolumn{1}{|c|}{ Pengaruh } & Terhadap & R Square \\
\cline { 1 - 1 } Standar Akuntansi Pemerintahan (SAP) & LK & 0,644 \\
\cline { 1 - 2 } Kualitas Aparatur Pemerintahan (SDM) & & 0,193 \\
\cline { 1 - 2 } Laporan Keuangan (Lk) & SAP & \\
\hline
\end{tabular}

Sumber : Hasil olahan PLS, 2020

Tabel 2 diatas menunjukkan bahwa koefisien determinasi (R-square) yang didapatkan dari model variabel standar akuntansi pemerintahan dan kualitas aparatur pemerintahan sebesar 0,644 sehingga dapat dijelaskan bahwa variabel laporankeuangan dapat dijelaskan oleh variabel standar akuntansi pemerintahan dan variabel kualitas 
aparatur pemerintahan sebesar $64,4 \%$ dan sisanya $35,6 \%$ dipengaruhi oleh variabel lain diluar penelitian.

Tabel 3.

Pengujian Pengaruh Langsung dan Pengaruh Tidak Langsung

\begin{tabular}{|c|c|c|c|c|c|c|c|c|}
\hline \multirow{2}{*}{ Hipotesis } & \multicolumn{3}{|c|}{ Variabel } & \multirow{2}{*}{$\begin{array}{l}\text { Direct } \\
\text { Effect }\end{array}$} & \multirow{2}{*}{$\begin{array}{l}\text { Indirec } \\
\text { t Effect }\end{array}$} & \multirow{2}{*}{$\begin{array}{l}\text { Total } \\
\text { Effect }\end{array}$} & \multirow{2}{*}{$\begin{array}{c}\text { Statistic } \\
>1,96\end{array}$} & \multirow{2}{*}{ Ket } \\
\hline & Eksogen & $\begin{array}{c}\text { Interve } \\
\text { ning }\end{array}$ & $\begin{array}{c}\text { Endo } \\
\text { gen }\end{array}$ & & & & & \\
\hline 1 & $\mathrm{X} 1$ & - & $\mathrm{Y}$ & 0,385 & - & 0,385 & 1,334 & TS \\
\hline 2 & $\mathrm{X} 2$ & - & $\mathrm{Y}$ & 0,555 & - & 0,555 & 1,995 & S \\
\hline 3 & $\mathrm{X} 1$ & - & $\mathrm{X} 2$ & 0,439 & - & 0,439 & 1,949 & TS \\
\hline 4 & $\mathrm{X} 1$ & $\mathrm{X} 2$ & $\mathrm{Y}$ & 0,439 & 0,244 & 0,683 & 0,586 & TS \\
\hline
\end{tabular}

Sumber : Hasil olahan PLS, 2020

\section{Pengaruh standar akuntansi pemerintahan terhadap laporan keuangan}

Hasil analisis menunjukkan bahwa koefisien jalur pengaruh langsung standar akuntansi pemerintahan terhadap laporan keuangan diperoleh nilai sebesar 0,385 pada tstatistik 1,334. Hal ini membuktikan bahwa standar akuntansi pemerintahan berpengaruh tidak signifikan terhadap laporan keuangan. Koefisien jalur bertanda positif dapat diartikan bahwa hubungan standar akuntansi pemerintahan dengan laporan keuangan pada dinas pekerjaan umum dan penataan ruang kabupaten karimun adalah searah. Dengan demikian, tidak terdapat cukup bukti secara empiris untuk menolak hipotesis (H0) dan menerima hipotesis (H1), bahwa semakin tinggi standar akuntansi pemerintahan maka semakin meningkat atau terupdate laporan keuangan pada pemerintahan kabupaten karimun.

\section{Pengaruh kualitas aparatur terhadap laporan keuangan}

Hasil analisis menunjukkan bahwa koefisien jalur pengaruh langsung kualitas aparatur pemerintahan terhadap laporan keuangan pemerintah daerah diperoleh nilai sebesar 0,555 pada t-statistik 1,994. Hasil ini membuktikan bahwa kualitas aparatur pemerintah berpengaruh signifikan terhadap laporan keuangan. Koefisien jalur bertanda positif dapat diartikan bahwa hubungan kualitas aparatur pemerintahan dengan laporan 
keuangan pemerintahan pada dinas pekerjaan umum dan penataan ruang kabupaten karimun adalah searah. Dengan demikian terdapat cukup bukti secara empiris untuk menolah hipotesis (H0) dan menerima hipotesis (H1), bahwa semakin berkualitas aparatur pemerintahan atau sumber daya manusia akan meningkatkan laporan keuangan.

\section{Pengaruh standar akuntansi pemerintahan terhadap kualitas aparatur pemerintahan}

Hasil analisis menunjukkan bahwa jalur pengaruh langsung standar akuntansi pemerintahan terhadap kualitas aparatur pemerintahan diperoleh nilai sebesar 0,439 pada t-statistik 1,949. Hasil ini membuktikan bahwa standar akuntansi pemerintahan berpengaruh tidak signifikan terhadap kualitas aparatur pemerintahan. Koefisien jalur bertanda positif dapat diartikan bahwa hubungan standar akuntansi pemerintahan dengan kualitas aparatur pemerintahan pada dinas pekerjaan umum dan penataan ruang kabupaten karimun adalah searah. Dengan demikian tidak terdapat cukup bukti secara empiris untuk menolak hipotesis (H0) dan hipotesis (H1) diterima, bahwa semakin tinggi standar akuntansi pemerintahan, akan meningkatkan kualitas aparatur pemerintahan.

\section{Sobel Test}

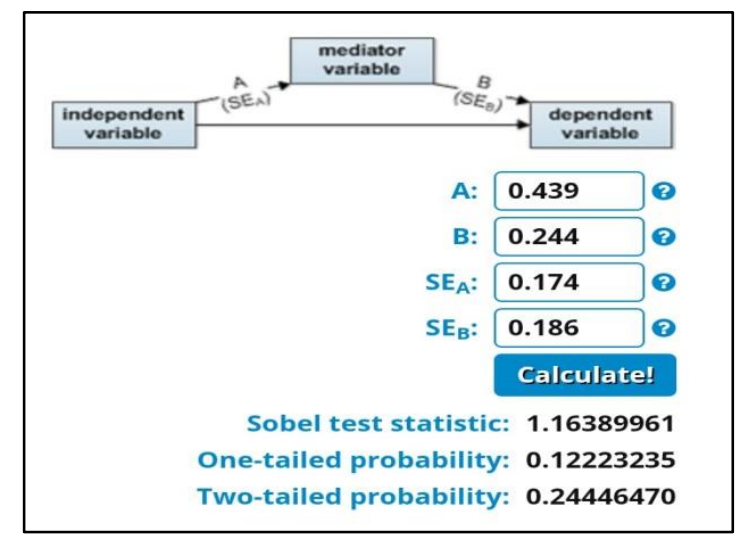

Gambar 2.

Hasil perhitungan Sobel Test

Dari hasil perhitungan sobel test pada gambar diatas mendapatkan nilai z sebesar $1,163<1,96$ (batas nilai z kurva normal) dengan tingkat signifikan $5 \%$. Hasil ini membuktikan bahwa standar akuntansi pemerintahan berpengaruh tidak signifikan 
terhadap laporan keuangan melalui mediasi kualitas aparatur pemerintahan. Koefisien jalur bertanda positif dapat diartikan bahwa hubungan standar akuntansi pemerintahan dengan laporan keuangan melalui kualitas aparatur pemerintahan adalah searah. Dengan demikian terdapat cukup bukti secara empiris untuk menolak hipotesis (H0) dan menerima hipotesis (H1), bahwa standar akuntansi pemerintahan merupakan prinsipprinsip akuntansi yang diterapkan dalam menyusun laporan keuangan pemerintah daerah melalui kualitas aparatur pemerintahan pada Dinas Pekerjaan Umum dan Penataan Ruang Kabupaten Karimun.

\section{KESIMPULAN}

Berdasarkan dari analisis data penelitian dan pembahasan, maka dapat ditarik kesimpulan yaitu sebagai berikut:

1. Hasil uji hipotesis menunjukkan bahwa penerapan standar akuntansi pemerintahan berpengaruh tidak langsung terhadap laporan keuangan pemerintah daerah kabupaten karimun pada dinas pekerjaan umum dan penataan ruang kabupaten karimun. Standar akuntansi pemerintahan diperlukan untuk meningkatkan kualitas laporan keuangan yaitu meningkatan konsisten, daya banding, keterpahaman, relevansi, dan keandalan laporan keuangan, dan Standar Akuntansi Pemerintah juga merupakan persyaratan yang mempunyai kekuatan hukum dalam upaya meningkatkan kualitas laporan keuangan pemerintah.

2. Hasil uji hipotesis menunjukkan bahwa kualitas aparatur pemerintahan terdapat pengaruh yang signifikan terhadap laporan keuangan pemerintah daerah pada Dinas Pekerjaan Umum Dan Penataan Ruang Kabupaten Karimun, Manusia dalam hal ini pegawai adalah makhluk sosial yang menjadi kekayaan utama bagi setiap organisasi. Mereka menjadi perencana, pelaksana, dan pengendali yang selalu berperan aktif dalam mewujudkan tujuan organisasi. Pegawai menjadi pelaku yang menunjang tercapainya tujuan, mempunyai pikiran, perasaan dan keinginan yang dapat mempengaruhi sikap-sikap negatif hendaknya dihindarkan sedini mungkin. Maka secara langsung kualitas aparatur pemerintahan berpengaruh terhadap laporan keuangan pemerintahan daerah Kabupaten Karimun khusus nya pada Dinas Pekerjaan Umum Dan Penataan Ruang Kabupaten Karimun. 
3. Hasil uji hipotesis menunjukkan bahwa standar akuntansi pemerintahan berpengaruh tidak signifikan terhadap kualitas aparatur pemerintahan. dalam penerapan standar akuntansi pemerintahan apabila kualitas aparatur pemerintahan atau disebut sebagai pegawi melaksanakan tugas dan kewajibannya dengan tanggung jawab dan konsisten maka penerapan standar akuntansi pemerintahan akan dilakukan dengan baik dan benar oleh pegawai tersebut.

4. Hasil uji hipotesis menunjukkan bahwa standar akuntansi pemerintahan memiliki pengaruh tidak langsung terhadap laporan keuangan melalui kualitas aparatur pemerintahan, menunjukkan bahwa laporan keuangan yang disajikan dan disusun berdasarkan penerapan standar akuntansi pemerintahan melalui kualitas aparatur pemerintahan atau semberdaya manusia (pegawai) pada Pemerintah Daerah Kabupaten Karimun khususnya pada Dinas Pekerjaan Umum dan Penataan Ruang Kabupaten Karimun. 


\section{DAFTAR PUSTAKA}

Bastian, Indra. 2006, Akuntansi Sektor Publik: Suatu Pengantar, Erlangga, Jakarta.

Baridwan, zaki. 2009. Sistem Akuntansi. BPFEE, Yogyakarta.

Edy Prasetya, Gede. 2005, Penyusunan dan analisis laporan keuangan. Alrush Bookstore, Andi, Yogyakarta.

Dina Afrina, (2015), Pengaruh Penerapan Sistem Akuntansi Pemeritah Daerah, Pengendalian Intern Dan Sistem Pelaporan Terhadap Akuntabilitas Kinerja Instansi Pemerintah (Studi Persepsian Pada Satuan Kerja Perangkat Daerah Kota Pekan Baru), Jom FEKON Vol. 2 No. 2 Oktober 2015

Daniel Kartika Adhi danYohanes Suhardjo (2013). Pengaruh Penerapan Standar Akuntansi Pemerintahan Dan Kualitas Aparatur Pemerintahan Terhadap Kualitas Laporan Keuangan Studi Khasus Pada Pemerintah Kota Tual, JURNAL STIE SEMARANG, VOL 5, NO 3, Edisi Oktober 2013 (ISSN : 2252-7826).

Fahmi, Irham. 2012. Analisis Laporan Keuangan. Bandung: Alfabeta

Ikatan Akuntan Indonesia. 2002. Standar Akuntansi Keuangan. Jakarta : Salemba Empat.

Mulyadi, 2008. Sistem Akuntansi. Salemba Empat, Jakarta.

Martini, Dwi, dkk. 2012, Akuntansi keuangan menegah berbasih PSAK. Jakarta : Salemba Empat.

Olga Yani Fransiska Singkali dan Retnaningtyas Widuri (2014). Penerapan Standar Akuntansi Pemeintahan Pada Dinas Pendapatan Dan Pengelolaan Keuangan Aset Daerah (DPPKAD) Kabupaten Toraja Utara, Tax \& Accounting Review, Vol 4, No 2, 2014

Peraaturan Pemerintah No. 71 tahun 2010.

Sumarsono, Sony. 2010, Manajemen keuangan pemerintahan. Yogyakarta: Graha Ilmu.

S, Munawir. 1991. Analisa Laporan Keuangan. Cetakan kedua. Yogyakarta: Penerbit Liberty.

Tanjung, abdul hafiz. 2012. Akuntansi Pemerintahan Daerah BerbasisAkrual, Pendekatan Teknis Sesuai PP No. 71/2010. Alfabeta, Bandung.

Tegor, dkk. 2020. Metodologi Penelitian Kualitatif dan Kuantitatif. Yogyakarta: Lakeisha 